\title{
SEDIMENTOLOGY - SOME \|ा局 UNRESOLVED PROBLEMS AND NEW DIRECTIONS
}

In this article eight sedimentologists briefly outline some of the major current issues in their special fields, ranging from deep to shallow water to terrestrial environments, and from modern to ancient deposits and processes. The first summary previews an international workshop on fine-grained sediments scheduled for Halifax, Nova Scotia, Canada, in August, 1982. The other seven contributions relate to special sessions organized by the International Association of Sedimentologists (IAS) at its 11 th Congress being held in Hamilton, Ontario, Canada, also in August.

\section{Toward an Anatomy of Fine-Grained Sediments}

\author{
by
}

Dorrik A.V. Stow

\begin{abstract}
"Possibly many may think that the deposition and consolidation of fine-grained mud must be a very simple matter, and the results of little interest. However, when carefully studied ... it is soon found to be so complex a question, and the results dependent on so many variable conditions, that one might feel inclined to abandon the inquiry, were it not that so much of the history of our rocks appears to be written in this language." (Henry C. Sorby, 1908)

Fine-grained sediments such as muds, silts, and oozes make up as much as 70 per cent of ocean basins fill as well as the modern cover of coastal areas and continental shelves. Although thick sequences of shales and chalks are abundant in the geological record, their apparent monotony has meant they have been relatively neglected by land geologists. The importance of this class of rocks is only now being rediscovered.
\end{abstract}

The understanding of fine-grained sediments has a valuable practical application; they are the source rocks for hydrocarbon generation, the substrate for sub-sea constructions, and the mobile coastal and fluvial sediments for environmental management. For these reasons, new work in sedimentology has been focussed at the fine end of the spectrum (e.g. Potter, Maynard and Pryor, 1980). Three frontier areas of research and discovery are outlined below:

Black shales are widespread organic-rich mudstones concentrated at certain stratigraphic intervals. Those of the Jurassic and Cretaceous periods are the source of most of the world's oil and gas. It is believed that they formed in restricted basins or where an expanded oxygen minimum impinged on the sea floor during an Oceanic Anoxic Event (Schlanger and Jenkyns, 1976; Thiede and Van Andel, 1977). Recent work has shown that their distribution and nature result from a more complex interplay of controls, including water mass circulation and stratification, water temperature, salinity and oxygen content, biological productivity, sedimentation rate and process and sea level changes. Careful integration of sedimentological, organic and inorganic geochemical studies should provide new insights into the regional and temporal variability of these controls and their effects on the sediments.
Silt and mud turbidites are abundant in the marine environment but they do not readily conform to the laws and models for classical sandy turbidites formulated in the $1950 \mathrm{~s}$ and '60s. A recently-proposed facies model for the standard structural sequence in fine clastic turbidites ( $S$ tow and Shanmugam, 1980) shows that the complete sequence has nine subdivisions: $T_{0}$ - a basal silt lamina with sharp scoured base, internal lamination and fading-ripple top, $T_{1}$ - a graded silt-laminated unit with convolute laminae, $\mathrm{T}_{2}$ - low-amplitude ripple laminae, $\Upsilon_{3}$ - regular thin laminae, $T_{4}$ - indistinct laminae and $T_{5}$ - wispy laminae; and a graded $T_{6}$ - to ungraded mud $T_{7}$ - unit, bioturbated toward the top $T_{8}$. Similar work is in progress on fine carbonates.

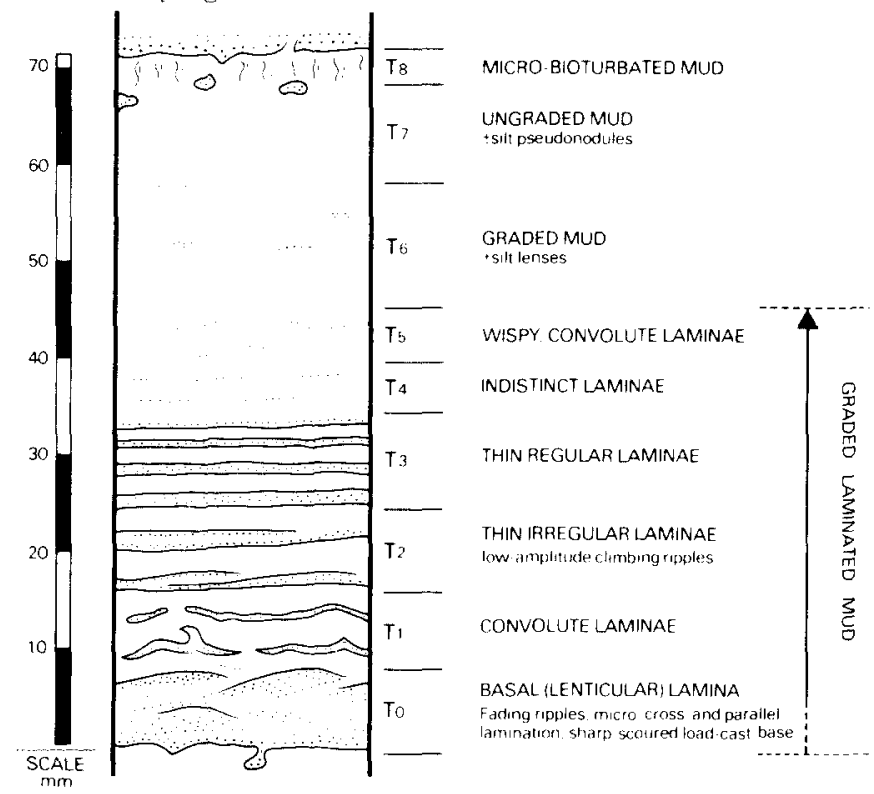

Idealized sequence of structures in fine-grained turbidite. Equivalent to topmost CDE Bouma sequence. Stipple = silt, blank $=$ mud. From: D.A.V. Stow and G. Shanmugam, 1980. 
Muddy contourites form huge, elongate sediment drifts in the open oceans that mark the passage of deep thermohaline currents (Stow and Lovell, 1979). Undiscovered until the early 1960s, recognition of these sediments in past sequences provides a valuable new tool for the reconstruction of palaeocirculation and palaeoenvironments.

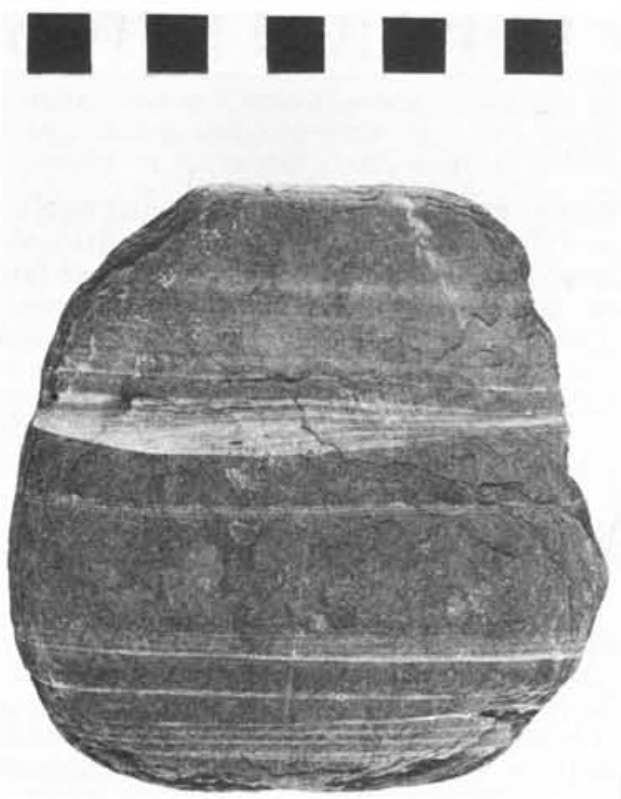

Fine-grained turbidites with "fading-ripple", an isolated example of Type C ripple-drift cross-lamination, Halifax Formation, Nova Scotia. Scale in $\mathrm{cm}$.

In these and in other areas of fine-grained sedimentology, future advances will doubtless come from a two-pronged attack - on the one hand, the very detailed resolution of mud properties at the finest scale, and on the other, the mechanistic approach to larger-scale processes and controls of sedimentation.

\section{References}

Potter, P.E., Maynard, J.B. and Pryor, W.A., 1980, Sedimentology of Shale: Springer-Verlag, 303 p.

Schlanger, S.O. and Jenkyns, H.C., 1976, Cretaceous oceanic anoxic events: causes and consequences: Geol. Mijnbouw 55 , p. $179-184$.

Stow, D.A.V. and Lovell, J.P.B., 1979, Contourites: their recognition in modern and ancient sediments: Earth Science Reviews 14, p. 251-291.

Stow, D.A.V. and Shanmugam, G., 1980, Sequence of structures in fine-grained turbidites: comparison of recent deep-sea and ancient flysch sediments: Sed. Geol. 25, p. 23-42.

Thiede, J. and Van Andel, Tj.H., 1977, The palaeoenvironment of anaerobic sediments in the late Mesozoic South Atlantic Ocean: Earth Planet. Sci. Lett. 33, p. 301-309.

\section{ABOUT THE AUTHOR:}

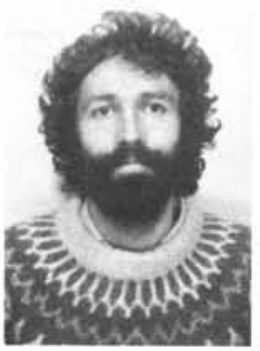

After doctoral studies at Dalhousie University, Halifax, Nova Scotia, Dr. Dorrik A.V. Stow joined the British National Oil Corporation in 1977. In 1980 he went to the Grant Institute of Geology, University of Edinburgh, West Mains Road, Edinburgh EH9 3JW, U.K., where he works in the field of fine-grained sedimentation and petroleum sedimentology. He is as much at home on the swell of the ocean as rock-tapping on land, and is a keen member of AGID with interests in energy resources and the law of the sea.

\section{Effects of Organisms on Sedimentary Models}

by

Michael J. Risk

Geologists have been aware for more than a century that animals affect the sediments in which they live, and that they can produce markings that are preserved in the rock record. The study of these markings has developed into ichnology, a subdiscipline of paleontology.

In the past few years ichnological research has moved away from describing and naming trace fossils, and has concentrated increasingly on the use of traces to provide essential data on environments of deposition. At the same time, a small number of scientists with experimental/biological interests in animal-sediment relations have been producing data on the effect of organisms on the chemical and physical dynamics of sediments.

Earlier phases of both lines of research, the descriptive and the experimental, tended to emphasize marine macrobenthos. Although this work has continued, there has been an encouraging trend toward working in freshwater environments, and in considering the effects of micro-organisms. Enough data are now available to show that organisms can control effective grain diameters, pickup and settling velocities, water and carbon content, mineralogy, physical and acoustic properties, and nutrient and trace element contents. In addition, the traces left in the rock record can provide information such as sedimentation rates, carbon content, physical properties, and environmental stability.

Although all this is well-known to "Bug People", who are aware of the effects of organisms on sediments, they sometimes feel they are engaged in a dialogue of the deaf with their sedimentologist colleagues. There has not been enough spreading "the word", nor receiving it - a problem in any new discipline. How many environmental reconstructions are based on grain-size analyses of peroxided sediment samples? Removal of the organic matter in any sediment, for example, by peroxiding, may destroy the original grain size distribution. 


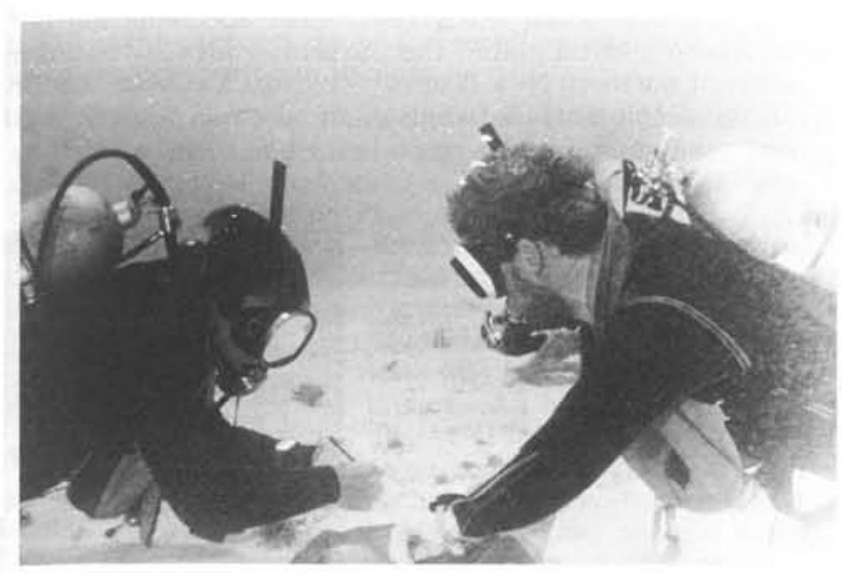

Two biologically-inclined sedimentologists $(l-T e r r y$ Scoffin, $r$-Sandy Tudhope) monitoring movement of a dyed sand tracer layer, Davies Reef, Great Barrier Reef.

Some of the specific topics investigated in recent studies include the lamination of lake sediments due to mass deaths of bacteria, refinement of facies models for the Athabasca
Oil Sands, rate of destruction of carbonate sands under zeroenergy conditions, growth of spar in limestones mediated by bacteria, control of nutrient fluxes in lakes, and the use of trace fossils to identify storm events in the geologic record.

The study of organic effects on sedimentary processes is like a newborn infant: its appearance is welcomed, there was a certain amount of fun in the creation, the noise and unpleasant byproducts must be endured, and there is hope that the potential will be realized.

ABOUT THE AUTHOR:

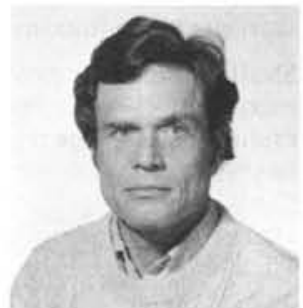

Dr. Michael J. Risk has been with the Department of Geology at McMaster University, 1280 Main Street West, Hamilton, Ontario, Canada L8S 4MI, since 1971, but has spent brief periods as a volunteer in Jamaica and Costa Rica, plus a year's sabbatical on the Great Barrier Reef. His main interests are animal-sediment relationships and coral reef ecology.

\section{Sedimentology of Coal and Coal-Bearing Sequences}

by

Ray A. Rahmani

The recent worldwide increase in the search for coal has sparked a dramatic growth by universities, government surveys, and the private sector in sedimentological research on the origin and formation of coal. This growth in coal research is also reflected by the steady rise in the number of papers being presented in sessions and symposia at annual national and regional meetings of $A A P G$ and IAS, for example. There has also been an expansion in the number of specialized coal geology meetings with very strong sedimentological emphasis (for example, the now biannual symposium on the Geology of Rocky Mountain Coal, and AAPG short courses).

Earlier depositional models of coal were essentially those originating from studies of the Carboniferous coals of western Europe and eastern United States (Appalachian). Most of these models were fashioned after the modern Mississippi River delta model. Coal sedimentologists working on other coal basins, especially the Mesozoic and Tertiary basins in the western interior of North America, gradually realized that other depositional models of coal formation were necessary to explain their geometry. Hence, alluvial fan, alluvial plain, back-barrier, wave- and tide-dominated delta models have been increasingly referred to in more recent coal studies.

Results of contemporary studies on modern peats caution coal sedimentologists that river deltas are not the only sites for development of potentially commercial coal-forming peats. More attention should be paid to coals that have accumulated on barred coastal plains, such as those of the Atlantic side of U.S.A. (Cohen, in press a,b); Otte and Ingram*). Cohen (in press b) suggests that coal-forming peats forming contemporaneously with major active river deltas are not as common as was originally thought, and that their formation may be the direct result of delta lobe abandon- ment. Other workers speak of coal forming in semi-arid environments (Legun and Rust, 1981), although such deposits may be of little commercial value.

Depositional and facies models of coal are now being used in (1) planning exploration programs; (2) planning underground and surface mines; (3) locating sites for in-situ underground coal gasification; and (4) estimating coal resources. The list of existing coal depositional models is by no means complete, and the trend of refining established models and introducing new ones is expected to continue.

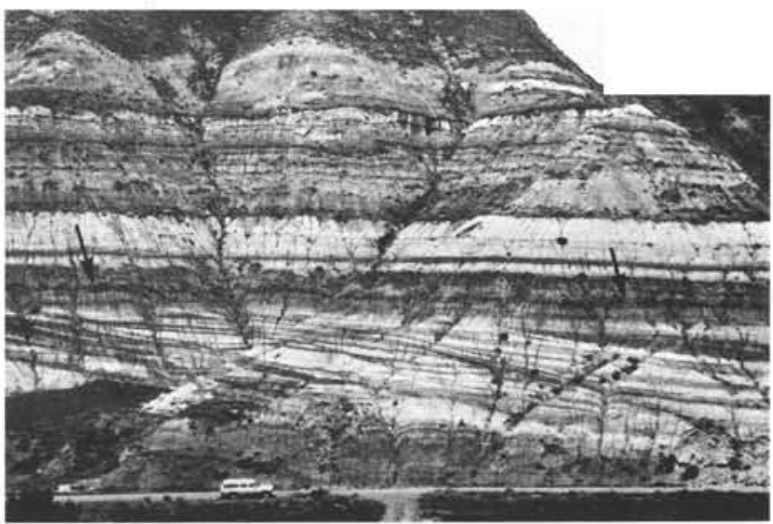

Tide-dominated shoreline coal-bearing sequence. Upper Cretaceous molasse, Drumheller, Alberta, Canada. Arrows point to 50-cm-thick coal seam. Below the coal seam is a 10-mthick tidal estuarine point bar with accretion bedding dipping to the right. Underneath the point bar (at and above level of the truck) is prodelta shale. Above the coal seam is a complex of back-barrier subtidal channels, intertidal flats and shoals and minor coal seams. 
In order to establish and introduce predictive depositional models for coal, an integrated approach to studies of both modern peats and modern depositional systems is required. Hence, there is obviously a need for continued and increased effort in the study of modern peats of the various climatic zones. Another fruitful line of research, and one that would have considerable application as an exploration tool at least in the Rocky Mountains and similar basins, is the realization that sites of thick coal accumulation occur at regressive and transgressive maxima (Ryer ${ }^{*}$ ).

Shallow seismic exploration for coal should furnish the sedimentologist with further additional data with which to decipher the geometry of coal seams in downdip parts of coal basins. Perhaps the time is now ripe for an effort to relate the various types of coal accumulation models to tectonic styles and to develop a new classification of coal basins accordingly.

\section{References}

Cohen, A.D., in press (a), Okefenokee swamp: A low sulphur end member of a depositional model for coastal plain coal: Proceedings of Coal Symposium, 9th International Congress of Stratigraphy and Geology of the Carboniferous, Elsevier.

Cohen, A.D., in press (b), Predicting characteristics of coal seams from studies of modern peat deposits: Coal Geo$\log y$.
Legun, A.S. and Rust, B.R., 1981, Coal accumulation on a semi-arid alluvial plain: the Carboniferous Clifton Formation of northern New Brunswick: (Abs.), Annual meeting of the Geological Association of Canada, Calgary, Alberta, v.6, p. A-65.

\section{ABOUT THE AUTHOR:}

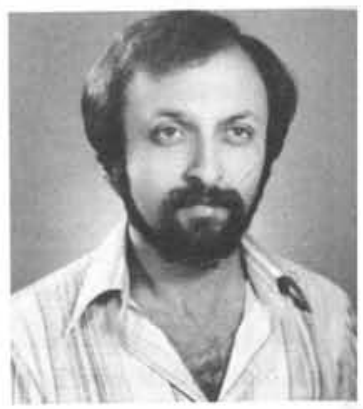

Dr. Ray A. Rahmani is a graduate of the University of Alberta and is now Associate Research Officer with the Alberta Geological Survey, 4445 Calgary Trail South, Edmonton, Canada T6H 5R7. He is involved in research on the depositional environments and facies relationships of the coal-bearing Cretaceous and Tertiary rocks of the Rocky Mountain molasse basin of Alberta. Prior to this he worked with Shell Canada, GSC, and in Kuwait on clastic rocks of Mesozoic and Tertiary age.

\section{Carbonate Petrogenesis}

Noel P. James

The present is the key to the past: this axiom, coined almost 100 years ago, is the essence of modern sedimentology. It is particularly true for carbonate petrogenesis where detailed study of modern tropical environments and documentation of diagenetic processes in Pleistocene limestones have resulted in increasingly sophisticated and complex interpretations of ancient rocks. Recently, however, many workers have begun to question direct application of the modern analogue to the rock record.

One of the first modern environments to be documented in detail, for example, was the muddy carbonate tidal flat. The

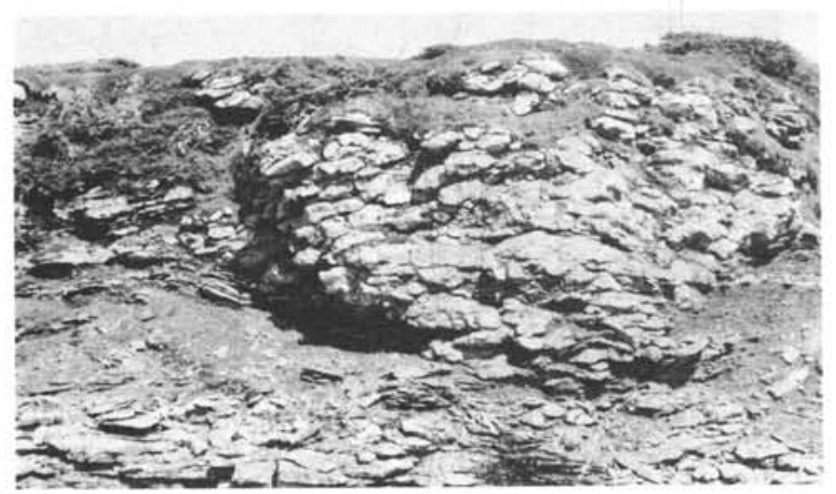

An early Cambrian bioherm ca $8 \mathrm{~m}$ high exposed along the northern cliffed shoreline of the Strait of Belle Isle, southern Labrador, Canada. These build-ups, formed soon after the appearance of skeletal metazoans, exhibit all the attributes of reefs which grew in the later Phanerozoic. findings from these modern flats are easily applied to carbonate strata which show evidence of periodic exposure. The applicability of models derived mostly from the study of narrow shelves to vast Cambro-Ordovician epeiric platforms, is being challenged by R.N. Ginsburg* who suggests several different possibilities for separate parts of the geologic record. A major question in this controversy is whether these ancient deposits were "tidal" at all.

On a larger scale, the single most critical factor in the carbonate equation is calcareous algae. In modern oceans they are volumetrically the single most important sediment producers - green and red algae form muds and sands on shallow carbonate shelves; coccoliths form deep sea oozes. Some of these algae have only recently evolved - what was carbonate sedimentation like without them?

The geologic history of reefs is also being reconsidered in light of reef studies at critical "turning points" in geologic history. N.P. James* and his co-workers have found that the reef ecosystem, complete with cavities, submarine cements, and endolithic organisms, was present soon after skeletal metazoans appeared in Early Cambrian time. Once established, this ecosystem seems to have survived throughout the Phanerozoic and passed through the Permian crisis remarkably well. In their work on Triassic reefs, Flugel (1981) and his colleagues recognize that forms in Middle Triassic reefs are remarkably Permian-like but are quickly replaced by faunas of scleractinian corals, sponges, and hydrozoans "sclerosponges" of more open "modern" aspect. Despite this somewhat clearer picture of skeletal reefs, carbonate mudmounds remain an enigma. Detailed examination of Silurian mounds by P.A. Bourque* and H. Gignac* suggests that now 
vanished siliceous sponges were the main elements, yet B.R. Pratt* presents equally compelling evidence that algae were the dominant components.

The field of carbonate diagenesis is equally confused. After studying modern and fossil ooids several years ago, Sandberg (1975) suggested that calcite and not aragonite was the dominant precipitate on Paleozoic platforms. B.H. Wilkinson (1980) extended this to skeletal elements and updated an earlier concept that most skeletal-producing organisms in Paleozoic seas were calcitic and not aragonitic, as they are today. Wilkinson and his students suggested at that time in the Ordovician low-Mg calcite was precipitating from shallow sea water. Placing these findings in a broader geological perspective, Mackenzie and Pigott (1981) feel they can relate these variations in marine carbonate to global changes in carbonate and sulphur recycling. Finally, Tucker (1982) has suggested that, on the basis of textural and isotopic evidence, dolomite and not calcite was the dominant precipitate in Precambrian seas. After years in disfavour, primary dolomite returns again'

If these ideas are correct, then one of the cornerstones of carbonate petrology is indeed shaky. Or are these observations really the result of variations in early, meteoric diagenesis. As C.F. Klappa* points out, what was meteoric diagenesis like when there were no land plants or true soils to modify meteoric waters?

\section{References:}

Flugel, E., 1981, Paleoecology and facies of Upper Triassic Reefs in the Northern Calcareous Alps: In Toomey, D.F., (ed.), European Fossil Reef Models. Soc. Econ. Paleo. and Min. Spec. Publ., No. 30, p. 291-361

MacKenzie, F.T. and Piggott, J.D., 1981, Tectonic controls of Phanerozoic sedimentary rock cycling: J. Geol. Soc. London, v. 138, p. 183-196.
Sandberg, P.A., 1975, New Interpretations of Great Salt Lake Ooids and of Ancient Non-Skeletal Carbonate Mineralogy: Sedim. 22, p. 497-537.

Tucker, M., 1982, Precambrian dolomites: petrographic and isotopic evidence that they differ from Phanerozoic dolomites: Geology, v. 10, p. 7-12.

Wilkinson, B.H., 1980, Biomineralization, paleoceanography and evolution of calcareous marine organisms: Geology, v. 8 , p. 265-267.

\section{ABOUT THE AUTHOR:}

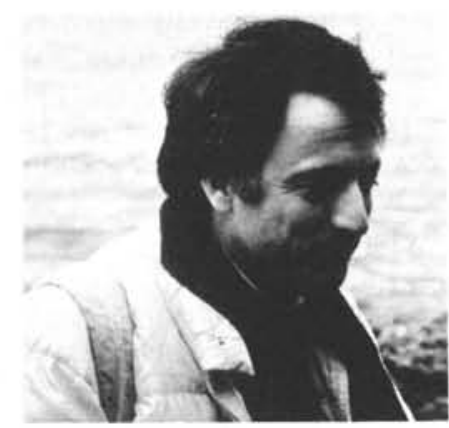

Dr. Noel P. James is a graduate of McGill University and worked for several years in the petroleum industry. He is now Professor of Earth Sciences at Memorial University, St. John's, Newfoundland, Canada A1B 3X5, where he teaches sedimentary and petroleum geology, and carries out research on Palaeozoic carbonates of western Newfoundland and southern Labrador and on modern carbonates in the Caribbean. He is well-known for his synthesis (with R.N. Ginsburg) on the recent carbonates and coral reefs of the Belize (British Honduras) continental shelf and slope.

\section{Gravels and Conglomerates}

by

Emlyn H. Koster

While gravel is fairly common in Pleistocene and Recent surficial deposits associated with glaciation, conglomerates form a localized and relatively infrequent part of the stratigraphic record. The stimulus for sedimentological studies of conglomerate, however, comes from their particular significance in deciphering tectonic activity, basin instability and provenance. Terrestrial conglomerates also host gold and uranium placer deposits and, together with marine conglomerates, they play a locally important role as hydrocarbon reservoirs. Pleistocene and Recent gravels function as aquifers and sources of construction aggregate.

Occurrences of terrestrial conglomerate reflect both the production of coarse detritus at nearby erosional sites and the availability of competent mass movement and/or fluvial processes. High relative relief and an arid climate are associated factors. Drainage systems may supply mature gravel to nearby coastlines for shoreline and inner shelf redistribution. Research earlier this century concentrated on these environments and processes in terms of a few case histories (notably those of W.C. Krumbein), formulation of descriptive measures for gravel clasts, and preliminary work to unravel their hydrodynamic behaviour.

Since the late 1960s, major new components in research have been the following:
- the documentation and initial understanding of coarse, often bouldery ancient deposits due to resedimentation mechanisms operating in submarine canyon-fan systems (Walker, 1975);

- an emerging comprehension of the full range of stratigraphically significant environments with gravel facies in molasse settings (Rust, 1979);

- a marked increase in the detail of studies on modern gravelly alluvium (for example, N.D. Smith and J.B. Southard*); and

- a broadened scope in experimental and theoretical work concerning gravel transport and deposition (Koster et al., 1980).

Compared to other types of sedimentary deposits, studies of gravel-size sediments require careful collection of data at the outcrop, where the essential ingredients for a complete description are framework/matrix texture, clast fabric, internal/over-all bedding character, and a petrologic classification of the coarse fraction. Recent studies of conglomerate in varied tectonic settings have been increasingly integrated with the process-response models derived from modern environments and simulation work. Progress toward a more sophisticated understanding of gravel facies, however, depends on detailed, comprehensive descriptions becoming the norm (R.J. Steel*). 
It is now known that conglomerate has accumulated in a wide variety of environments - subaerial fans with varying proportions of debris flow and fluvial processes, pediments, fluvial braidplains, fan deltas, beaches, wave-cut platforms, and inner shelf and submarine canyon-fan systems. Their tectonic association includes classic foreland molasse, yoked intracratonic basins, incipient intercontinental rifts, transcurrent pull-apart basins and later stage molasse basins within orogenic belts, and unstable margins of continental crust. An additional environment which has been the subject of a few recent sedimentological studies concerns modern and ancient gravelly deposits in volcanic flanks in zones of plate convergence.

The IAS Congress in August will be the first meeting of an international group of researchers working on these varied occurrences of rudite.

\section{References}

Koster, E.H., Rust, B.R. and Gendzwill, D.J., 1980, The ellipsoidal form of clasts with practical applications to fabric and size analyses of fluvial gravels: Can. Jour. Earth Sci., v. 17, p. 1725-1739.

Rust, B.R., 1979, Coarse alluvial deposits: In R.G. Walker (ed.) Facies Models, Geoscience Canada Reprint Series 1, p. 9-21.
Walker, R.G., 1975, Generalized facies models for resedimented conglomerates of turbidite association: Bull. Geol. Soc. America, v. 86, p. 737-748.

\section{ABOUT THE AUTHOR:}

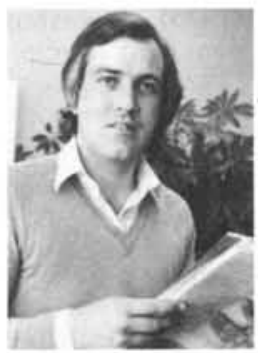

Dr. Emlyn H. Koster joined the Alberta Geological Survey and Research Council, Natural Resources Division, 4445 Calgary Trail South, Edmonton, Alberta, Canada T6H 5R7, in 1980. Prior to that he was an Assistant Professor at the University of Saskatchewan (1977-80), and Concordia University (197677). His Ph.D at the University of Ottawa dealt with flume studies of gravel transport and deposition. Although he is now a Project Manager for the Cretaceous-Tertiary coal geology program at the Research Council, he maintains a strong interest in the sedimentology of gravels and conglomerates.

\section{Large-Scale Sandy Bedforms}

by

\section{Robert W. Dalrymple}

Large-scale, flow-transverse bedforms (those with heights > $0.05 \mathrm{~m}$ and wavelengths $>0.6 \mathrm{~m}$ ), or the cross-stratification produced by them, are abundant in many sedimentary environments and their ancient deposits. Precise environmental and paleohydraulic interpretation of these deposits requires a detailed understanding of the link between the cross-stratification and the bedform dynamics (their inception, growth, and migration history), and between the bedforms and the current regime responsible for them. Progress has been made in both of these areas during the past few years, but many questions remain.

The most vexing problems relate to the classification of large-scale bedforms, and particularly superimposed relationships in which large-scale forms occur on still larger ones. Some workers believe that only one hydrodynamically-distinct type of large-scale bedform exists (for example, dunes). They explain the superposition as the result either of timevarying (unsteady) flow and delayed (lagged) response of the bedforms, with only one bedform size in equilibrium with the flow at any one time (bedform size scaling with flow speed and depth; Allen, 1978), or of an internal boundary layer developed on the stoss side of the larger form (Rubin and McCulloch, 1980).

Others (for example, Costello and Southard, 1981) believe that three or more hydraulically and morphologically distinguishable bedform types exist: "two-dimensional" dunes (also known as megaripples), with straight to gently sinuous crests; "three-dimensional" dunes with laterally continuous but more sinuous to lunate crests and scour pits; and sandwaves (larger features with superimposed dunes). The terminology used for these different types has also become very confused, particularly as the term sandwave has been used both for the larger features and as a synonym for two-dimensional dunes. This latter usage should be discouraged (Costello and Southard, 1981).
Allen (1980b) has suggested that morphologically similar, large sandwaves in fluvial and tidal environments may not be dynamically equivalent because reversing tidal flows, unlike unidirectional currents, produce a convergence of sediment toward the sandwave crests. The many recent descriptions of sandwaves in various shallow marine settings (SE Africa, eastern United States, Bay of Fundy, Bering Sea, English Channel and southern North Sea) have added much to our knowledge of their distribution and the range of hydraulic conditions (commonly strongly intermittent) under which they exist. More detailed field studies of bedform dynamics in situations with varying degrees and types of unsteadiness are urgently needed to resolve the questions raised by Allen's $(1978,1980)$ theoretical studies of bedform lag and sediment transport convergence.

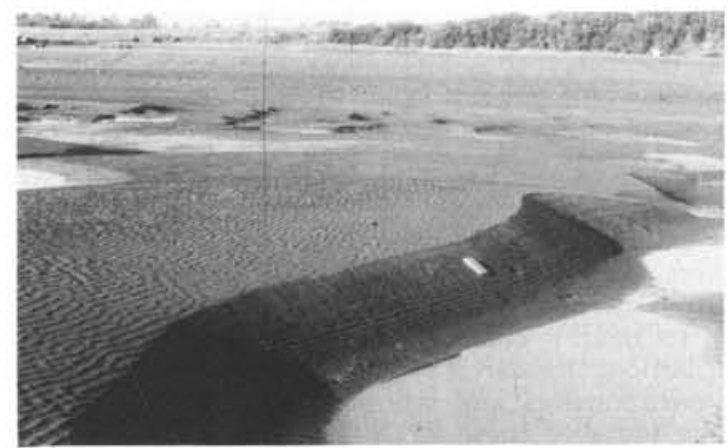

A large, ebb-asymmetric. megaripple with weakly-developed scour pits, transitional between two- and three-dimensional. Note also the late-ebb current ripples, and the falling-water marks on the megaripple lee face. Photo taken in the Avon River estuary, Bay of Fundy, Nova Scotia, Canada. Note book is $19 \mathrm{~cm}$ long. 
Investigations of the structures produced by large-scale bedforms have recently shown more concrete progress. Detailed examination of megaripple cross-bedding in an intertidal environment by Kohsiek and Terwindt (1981) has revealed that distinct changes in the nature of the forsets and topsets occur at specific current speeds. If this can be born out by similar studies in areas with different grain sizes and water depths, then it will provide a new and powerful tool for paleohydraulic reconstruction.

Controversy over the environmental interpretation (aeolian versus shallow marine) of very large-scale, high-angle crossbedding has also come a major step closer to resolution with the recent documentation of a suite of associated small-scale structures that are diagnostic of aeolian conditions (Hunter, 1977). The structures within modern shallow marine sandwaves have yet to be documented in such detail, but it has been suggested on theoretical grounds that they should contain smaller cross beds separated by inclined "master bedding planes" as a result of erosion by the subordinate tide (Allen, 1980b). This does not consider the possible influence of the superimposed dunes however. Studies like that conducted by Langhorne (1982) in which the migration history of a subtidal sandwave was monitored would do much to resolve many of the remaining questions about these large bedforms.

\section{References}

Allen, J.R.L., 1978, Polymodal dune assemblages: an interpretation in terms of dune creation-destruction in periodic flows: Sediment. Geol., v. 20, p. 17-28.

Allen, J.R.L., 1980a, Large transverse bedforms and the character of boundary-layers in shallow-water environments: Sedimentology, v. 27, p. 317-323.

Allen, J.R.L., 1980b, Sand-wave immobility and the internal master bedding of sand-wave deposits: Geol. Mag., v. 117, p. 437-446.
Costello, W.R. and Southard, J.B., 1981, Flume experiments on lower-flow-regime bedforms in coarse sand: Jour. Sed. Petrol., v. 51, p. 849-864.

Hunter, R.E., 1977, Basic Types of Stratification in Small Eolian Dunes: Sedimentology, v. 24, p. 361-387.

Kohsiek, L.H.M. and Terwindt, J.H.J., 1981, Characteristics of foreset and topset bedding in megaripples related to hydrodynamic conditions on an intertidal shoal: Intl. Assoc. Sedimentologists, Spec. Publ. 5, p. 27-37.

Langhorne, D.N., 1982, A study of the dynamics of a marine sand-wave: Sedimentology, v. 29, in press.

Rubin, D.M. and McCulloch, D.S., 1980, Single and superimposed bedforms: a synthesis of San Francisco Bay and flume observations: Sediment. Geol., v. 26, p. 107-231.

ABOUT THE AUTHOR:

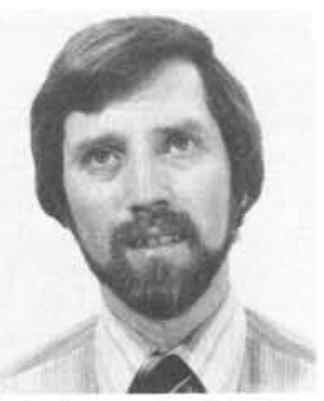

Dr. Robert W. Dalrymple has been an Assistant Professor in the Department of Geological Sciences, Queen's University, Kingston, Ontario, Canada K7L 3NG, since 1981. Prior to that he taught at Brock University in St. Catharines. He is currently Vice-President of Eastern Section, SEPM, and was the founding chairman of the SEPM Bedforms and Bedding Structures Research Group.

\title{
Eolian Sediments and Processes
}

\author{
by
}

Michael E. Brookfield

In the past decade, studies of eolian sediments and processes have "taken off". This is partly because satellite photographs now allow the broad patterns of features in modern deserts to be seen and partly because of the need to understand the processes taking place on the largest of the solar system deserts - those on Mars. A third factor has been the discovery in the western U.S.A. of important oil and gas reserves in eolian Mesozoic sandstones.

Satellite photos show that many deserts have simple largescale patterns of dunes and other features which vary systematically from one area to another. They also confirm the existence of bedform hierarchies that could be related to the wind regime operating in each desert or part of a desert (Wilson, 1973). Current work is aimed at developing models which relate the size, shape and distribution of desert features to the wind regime operating in each area. Although incomplete, this work indicates that for the first time it might be possible to develop models of desert development and evolution.

The need to study eolian processes on Mars has led to a resurgence in studies on the movement of sediment by the wind. Experimental studies using Earth and other planetary atmospheres have given a better understanding of how sediment is actually moved by the wind. In turn, this has led to a much better understanding on how eolian features develop (Iversen et al., 1976).

The need to develop predictive models in ancient eolian sandstones to aid in the search for oil and gas has also led to detailed studies on grain-size and stratification in these sandstones. The aim of these studies is to reconstruct the nature, distribution and size of ancient eolian bedforms, and to work out the evolution of the sand seas in which they developed. Studies of different types of stratification in modern dunes have allowed scientists to specify on which part of a dune strata were laid down, and to reconstruct the type and size of dune which formed the strata (Hunter, 1977). Combining current ideas on modern bedform patterns (from satellite photos) with the type of stratification developed in each bedform type, has led to the development of what an ancient desert was like and how it evolved in time (Kocurek, 1981).

The recent emphasis on deterministic, as opposed to stochastic, models of atmospheric turbulence, and the realization that atmospheric turbulence is arranged in regular arrays of vortex hierarchies, also makes it easier to visualize the interactions of bedforms and atmospheric flow. Fortunately, under conditions of sand movement in deserts, the planetary boundary layer (i.e., the layer of air within 1-2 km 


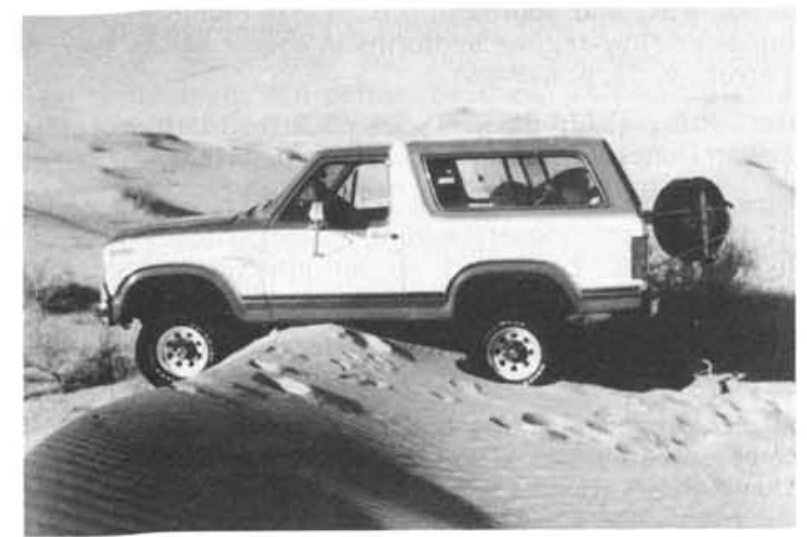

Dunes, El Gran Desierto, Sonora State, northwestern Mexico.

of ground surface) has only small thickness variations. Thus, the nasty complication of flow depth (found in aqueous flows) can be conveniently ignored (Brown, 1980).

We may soon be in the happy situation of being able to walk up to an outcrop of ancient eolian sediment and specify precisely where and how it formed: for example, "this was a transverse dune field in which the dunes were $5 \mathrm{~km}$ apart, 50 $\mathrm{m}$ high, and $3 \mathrm{~km}$ long, and it lay in the centre of a 100000 $\mathrm{km}^{2}$ desert with an average rainfall of $5 \mathrm{~cm} /$ year." But, we are not quite there yet!

\section{References}

Brown, R.A., 1980. Longitudinal instabilities and secondary flows in the Planetary Boundary Layer: Rev. Geophys. Space Phys. v. 18, p. 683-697.
Hunter, R.E., 1977, Basic types of stratification in small eolian dunes: Sedimentology, v. 24, p. 361-387.

Iversen, J.D., Pollack, J.B., Greeley, R. and White, B.R., 1976, Saltation threshold on Mars: the effect of interparticle force, surface roughness, and low atmospheric density: Icarus, v. 29, p. 381-393.

Kocurek, G., 1981, Erg reconstruction: the Entrada Sandstone (Jurassic) of northern Utah and Colorado: Palaeogeogr., Palaeoclimatol., Palaeoecol., v. 36, p. 125-153.

Wilson, I.G., 1973, Ergs: Sediment. Geol., v. 10, p. 77-106.

\section{ABOUT THE AUTHOR:}

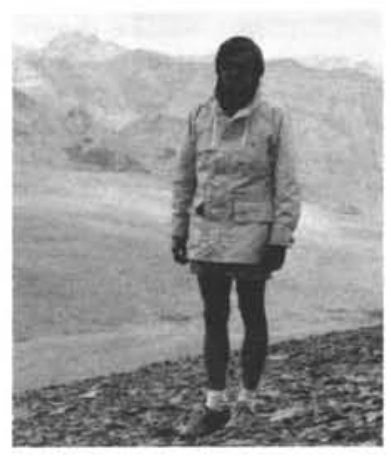

Dr. Michael Brookfield is Associate Professor in the Dept. of Land Resource Science, University of Guelph, Ontario, Agricultural College, Guelph, Ontario, Canada NIG 2W1. His current research interests are: the relationship of eolian bedforms to atmospheric structure, the tectonic development and palaeoenvironments of the Indus Suture Zone in India and Pakistan, and the palaeoenvironments of Ordovician shelf carbonates in Ontario.

\title{
Environmental Sedimentology
}

\author{
by
}

Dale E. Buckley

The influence of human activity on the quality of the global environment has been recognized by measurable changes in atmospheric constituents, alterations to the land surface and increased contamination of the oceans. Anthropogenic activities have influenced rates of erosion, sedimentation processes and the quality of depositional areas. Urban and industrial growth has resulted in the pollution of sediments carried by rivers or deposited in lakes and coastal marine areas. Accidents and persistent contamination associated with oil and other energy-related products have caused concern for the quality of many environments. Over the past two decades sedimentologists have been challenged to increase their role in contributing to the solution of these problems.

In future, sedimentologists will be required to do more than measure the effects that have already occurred as a result of human modifications to the environment. They will be required to predict the consequences of future developments and practices. The sedimentologist will have to improve skills in monitoring processes and developing predictive models. It will not be enough to rely on non-synoptic observations of a dynamic system such as an estuary to produce a predictive model of transport rates and depositional trends when it is well known that the estuary is influenced by variations in tidal flushing characteristics and seasonal variations in fresh water inflow. Future sedimentologists, especially those working in marine environments, will need to improve their knowledge of physics and venture into the field of quantitative modelling.

Technological tools which allow data to be collected on a synoptic basis are already being used in studies of suspended sediments. Remote sensing from artificial earth satellites is providing new insights into the complexity of the surface distribution of suspended sediments in turbid water systems. Sensitive acoustic profiling techniques are capable of detecting and quantifying suspended sediments concentrated in boundary layers. New monitoring "robots" are able to provide continuous time series data on a variety of simultaneous conditions such as current speed, water temperature, wave heights, tide stage, and even animal activity; all of these parameters may be significant in determining sedimentation conditions.

Because sediments are often the host for the concentration of pollutants, there is an increasing need for chemists and biologists to work closely with the sedimentologist. Problems associated with disposal of waste substances in natural water systems and at sediment dump sites are demanding precise knowledge of the likelihood of remobilization of contaminants. In these cases, the sedimentologist must not only be able to assess the probable risk of significant redistribution 


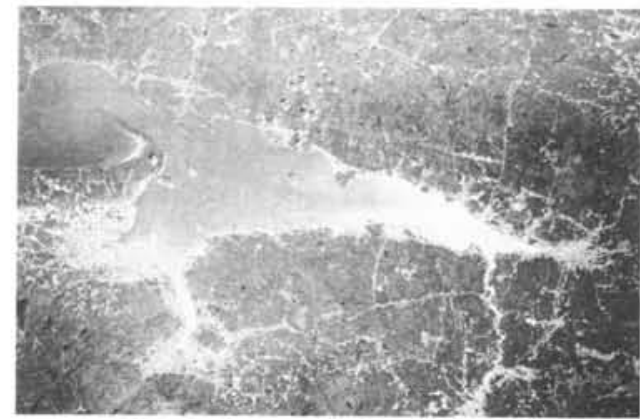

LANDSAT image of Minas Basin, Bay of Fundy, showing range of turbidity in water near head of the Bay. Image analyses can be used and calibrated with water samples to provide synoptic data on variations in suspended particulate matter in surface waters. Distance from left to right is 115 km.

of contaminants, but should be able to make recommendations, for example, on the use of stable cap sediments.

Planning major development projects such as hydroelectric generating systems, offshore production fields for oil and gas, and new port facilities will require that the impact of these developments are fully appreciated. This will mean that in many cases the engineer and sedimentologist must work compatibly as a team. In the past this cooperation has not existed, often with disastrous consequences. In order for a spirit of cooperation to exist when project feasibility studies are initiated, there must be mutual respect between the sedimentologist and engineer. Such trust will develop naturally when the engineer feels that the sedimentologist can approach problems analytically and, on the other hand, when the sedimentologist feels that the engineer appreciates the significance of accumulated effects of altered sedimentation processes.

New developments in the fields of sedimentology will require that teams of specialists work in close harmony to collect and interpret large volumes of interdisciplinary data. This type of approach is bound to be expensive and will demand that institutional resources be channelled to the research team rather than the isolated effort of individual scientists.

\section{ABOUT THE AUTHOR:}

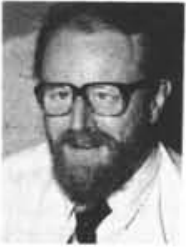

Dr. Dale Buckley is Head of Marine Inorganic Geochemistry at the Atlantic Geoscience Centre, Geological Survey of Canada, Bedford Institute of Oceanography, P.O. Box 1006, Dartmouth, Nova Scotia, Canada B2Y 4A2. Previously, he led studies in sedimentology and geochemistry in several estuarine and coastal marine areas of Atlantic Canada and the eastern Arctic. He has also been involved in studies of major oil spills, and at present is studying the geochemistry of deep sea sediments on the abyssal plains in the western Atlantic.

\section{NEW IUGS PUBLICATIONS}

Two new IUGS publications are now available:

Publication No. 3:

Cati, F., Steininger, F.F., Borsetti, A.M., and Gelati, R. (eds.). IN SEARCH OF THE PALAEOGENE/NEOGENE BOUNDARY STRATOTYPE. Part 1 . POTENTIAL BOUNDARY STRATOTYPE SECTIONS IN ITALY AND GREECE AND A COMPARISON WITH THE DEEP SEA. Bologna, Italy. 1981.210 p. with 19 plates. IUGS Publication No. 3: Price 60.000/copy (Italian Liras). A state-of-the-art review of the Palaeogene/Neogene Boundary undertaken by IUGS Commission on Stratigraphy.

Available from:

Giornale di Geologia,

Via Zamboni, 67,

1-40127 Bologna, Italy.

Series B, Number 4:

Craddock, C. (ed.) ANTARCTIC GEOSCIENCE. Published by the University of Wisconsin Press, Wisconsin, (1982), 1172 p. \$35.00 (U.S.). Proceedings of the 3rd Symposium on Antarctic Geology and Geophysics held in Madison, Wisconsin, U.S.A., August 1977. This is the last in Series B.

Available from:

The University of Wisconsin Press,

114 North Murray Street

Madison, Wisconsin 53715

U.S.A.

\section{IGC PUBLICATIONS}

The proceedings from the International Geological Congresses of Prague (1968), Montreal (1972), Sydney (1976), and Paris (1980) are available from the following addresses:

23rd IGC Prague (Czechoslovakia), 1968

Schweizerbart'sche Verlagsbuchhandlung Johannesstrasse $3 \mathrm{~A}$

D 7000 Stuttgart 1, F.R.G.

24th IGC Montreal (Canada), 1972

Université de Montréal

Departement de Géologie C.P. 6128

Montreal, P.Q., Canada H3C 337

25th IGC Sydney (Australia), 1976

University of Sydney

Department of Geology

2006 Sydney, Australia

26th IGC Paris (France), 1980

B.R.G.M.

SGN/EV

B.P. 6009

45060 Orleans Cedex, France 